International Journal of Management Science and

Business Administration

Volume 1, Issue 8, July 2015, Pages 7-13

DOI: 10.18775/ijmsba.1849-5664-5419.2014.18.1001

URL: http://dx.doi.org/10.18775/ijmsba.1849-5664-5419.2014.18.1001

\title{
Women in Marketing: Their Characteristics, Motivations, Challenges and Policy Implications
}

\author{
Ibok Nkanikpo Ibok ${ }^{1}$, Etuk Samuel George ${ }^{2}$ \\ Department of Marketing, University of Uyo, Uyo, Akwa Ibom State, Nigeria \\ Email: nkanikpo@yahoo.com
}

\begin{abstract}
Women constitute an important workforce in every society all over the world and contributions of women in every profession should be revisited with empirical facts. This study examines women in marketing; their characteristics, motivations and challenges using a survey method. With a sample of 60 respondents drawn across ten banks in Akwa Ibom State, the study reveals that characteristics, motivations and challenges of women has specific implications for national economic growth and marketing profession. Realizing overall empowerment of women in marketing and in the state, we recommend some policy guidelines as a way forward for utilization of women potentials.
\end{abstract}

Keywords: Women, Marketing, Motivations, Characteristics, Challenges

\section{Introduction}

Over the past few decades, there has been an increasing number of gender studies with particular interest on women in governance, women in politics, managerial positions, entrepreneurship, corporate organizations, professions etc. In Nigeria for example, nearly 65 percent of the studies on gender is about women (Anyanwu, 2012). Women are increasingly turning to many professions as a way of breaking the glass ceiling that seen to prevent them from getting to the top (Kishore, 1992; Lieunnan, 1992; Adetiba, 2009; and Adeuwsi, 2012).

However, as rightly observed by Morrison (2012), the entry of women into many professions is a recent development and a departure from traditional practices in many African States. In many African nations, the roles of women have traditionally been seen to be housewife and mother and they were expected to take on responsibility for household work and child rearing. The recent development among women to take on challenging office works amidst their family responsibility has created much concern in many quarters (Comper, 1991). Today, women are found virtually in all professions including marketing profession. Thus, identifying the characteristics of women marketers, their motivations and challenges will help in policy direction, especially, in countries such as Nigeria. Thus, while there have been several studies on women in many professions (e.g Kishore, 1992, Mishra 1986; Vaz, 1987), there have been very few studies on women marketers. This study, therefore, attempts to fill the gap in the literature by examining women marketers with a spot light on the banking industry in Nigeria. This is with a view to determining their socio-economic and demographic characteristics, their motivations and challenges in this profession. We hope that this study will guide policy direction for both the government and other sectors of the economy that will boost affirmative action in this direction. Against this backdrop, this study attempts to provide answers to the following research questions: What are the characteristics of women practicing marketing in the banking industry? What factors motivate their interest in this challenging profession? What challenges or problems do they encounter in the course of their practice? In order to provide answers to the research questions above, this study specifically is aimed at providing a profile of the women in marketing in the banking industry; examining the factors that motivate that interest in this job; and examining the problems faced by these women in the course of marketing for their banks. 


\section{Literature review}

Women all over the world have been observed to make significant contributions to national economic development and have ameliorated several economic and social problems in many societies (Lieunnan, 1992); Patel, 1987). For example, women are important sources of domestic productive labor in many areas. They also play important cultural roles especially, in home keeping. Women, therefore, play significant roles in sustaining society. However, range of women adaptation to different socio-economic spheres of life gives rise to several possible productive systems. There are quite a number of studies carried out from different disciplines on the role of women in different parts of the world but very few of them focused on the characteristics, motivations and challenges of this important sect in the banking industry which is the main concern of this study. The main thrust of this study, therefore, is to determine the socio-economic and demographic characteristics of women engaged in the banking industry as marketers, examine their motivations in the job and investigate the challenges confronting them with a view to proffering policy direction as a way of maximizing their potentials. Women constitute major component of the productive work force. Women play a vital role in the banking industry. On average, about 55 percent of the labor force in the banking industry and particularly, bank marketing in Nigeria are women (Comper, 1991). Thus, recent studies have continued to give evidence to the important contributions of women in all facets of the economy. For instance, in many developed economies, women sustain their families through household industries based on local raw materials (Lavoie, 1992). The investment contributions of women are not well documented by conventional data collecting methods. Available data (Kent, 1988) reveals that the investment pattern among women in many areas seem to be ignored due to the geographical and socio-economic factors such as income level, educational attainment, labor participation, but differ in degree of involvement, especially, in certain areas. Thus, the figure greatly vary from one country to another due to socio-cultural influences. It also vary as alternative sources of income are made available (Kent, 1992).

However, Neider (1987) shows that sexual harassment was an associated problem in bank marketing by female staff. Other serious problems affecting women marketers are fear of intimidation by management. This view has been persuasively presented in Neider's later study when he observed that professions have their peculiar problems depending on the managerial ability saddled with the constitutional rights or responsibilities of managing workforce. The availability of and efficiency of women marketers largely depends on the level of development of the society, poverty level, government commitment and political will among others. All these reveal the potency of the quality of the work environment, which in turn affects the level of women participation and the general development of the sector (Ibok, 2009). The presence of a tolerance work atmosphere in the banking industry go a long way in enhancing the contributions of women and affect the potentials derivable from this workforce. Along this line of thought, Stevenson (1986) argued that the possibility of a rapid integration of women in any productive workforce can be severely inhibited by the lack of job security and other related factors such as unrealistic sales target and outright discrimination against women. As observed by Adetiba (2009), bank marketing today is predominantly women affairs with very few men engaged as marketers. Thus, Jacob (2013) observed that sexual exploitation is the most crucial factor affecting women in this profession. Most banks employ beautiful young women and set unrealistic targets for them to generate within a given time frame. The problem of combating this menace in commercial banking practice has been a major concern to many in the banking industry. Other problems faced by women in their chosen profession include being accepted as a woman in business, lack of a role model, lack of professional interaction, difficulties in gaining the confidence of their clients, lack of adequate training and a lack of related experience (Belcourt, et al, 1991, Callerette and Aubry, 1990, Goffee and Sease, 1985, Hisrich and Brush, 1986, Kent, 1988, Lee- Gosselin and Grise, 1990, Timmons, 1986).

A study by Belcourt, et al (1991) pointed out that the most significant problem that women face is the tension between their personal lives, their career pursuits and work family balance. Neider (1987) in his study of female entrepreneurs in Flonida concluded that tension between women's personal life and career was a major problem to a large number of women. Adewusi (2012) in his thesis observed that women in many professional associations are denied certain privileges because of their lacking managerial experience and time factor. However, on the characteristics of women involved in bank marketing, Susan (2010), observed that over 65 percent of those marketing financial services are women. Utomi (2011) noted that these women are mostly under 35 years, mainly with college degrees and certificates. Akpan (2009) in a similar study of the profile of financial marketers observed that marketing bank services are mostly single with no children at home nor husband to cater for. Mojisola (2010) supported this claim by stating that 
educational level and marital status of women to be some of the isolated variables related to marketing profession. In their respective studies, majority of those involved in marketing financial resources were females, this does not suggest that males were not actively involved in marketing bank services. Olayide (1996) asserted that these category of staff are paid salary ranged between $\$ 80,000$ to $\$ 200,000$ per month, with variable pay condition. Bank marketing involves many travels and income is an important variable. To answer what drives women to this challenging task, Owen (2012) in her thesis, concluded that women involved in bank marketing as a way of actualizing their dreams for challenging task. Bebbington (2001) claimed that women choose to do marketing as an opportunity for self-fulfillment. Fulamiyo (2011) extended this study and observed that women mostly prefer to work as marketers for sake of being independent with flexible working hours. Along this line, Adelemo (2009) re-emphasized that women choose marketing as an opportunity for career advancement, while Okoruen (2012) in his submission observed that variable pay was the major attraction for bank marketers. This study has absorbed all the important areas of this research. It can be inferred from the available literature examined that the motivating factors and socio-economic/demographic profile in explaining the general development of the marketing profession, particularly in the banking industry as it relates to women.

\section{Research methodology}

The population of this study consisted of all the commercial banks in Akwa Ibom State. However, ten banks were taken as judgmental sample given such factors as financial resources, time and other constraints. The ten banks were selected based on their aggressive marketing pursuit. The study involves two stage sampling procedures. Ten banks were judgmentally selected which include: UBA, First Bank, Union Bank, FCMB, Diamond Bank, Sterling Bank, Zenith Bank, ETB, Fidelity and Main Street Bank. In the second stage, six women involved in marketing bank services from each bank were conveniently selected. This gives 60 female marketers totally. Primary data were collected through questionnaire. The questionnaire was validated by two professors who are well versed in gender studies from University of Port-Harcourt and University of Calabar. Their comments were taken in the revised copy of the questionnaire. The reliability of the research instrument was obtained through a test-retest reliability measure and subject to reliability alpha test. Obtained result was 0.86 or 86 percent, indicating that the instrument was reliable and can be used as proposed. Thus, the data collected for this study analyzed using descriptive statistics, which include tabular presentation, frequency and percentages of responses from our respondents. Although, participation among respondents was voluntary, we observed a heightened interest among women in this study.

\section{Data analysis and results}

This section presents the result and discussion of the study. The first sub-section is devoted to socio-economic and demographic characteristics of female marketers while sub-section was devoted to analysis of motivations and challenges faced by women. The result of the socio-economic characteristics of female marketers in the banking industry is presented in table 1 . Table 1 showed that 20 percent of the respondents are under 30 while 6.7 percent of them are 45 years and above. Majority $(73.3 \%)$ of them are between the ages of $31-44$. This indicates that women marketers cut across different age groups, thus age is no barrier to getting involved in bank marketing business. Table 1 also indicates that the large proportions $(80 \%)$ of the women are single, $13.3 \%$ of them are married, while few of them $(6.7 \%)$ are either widow or divorced. Table 1 further revealed that $6.7 \%$ of the respondents received FSLC or GCE, $26.6 \%$ received OND or NCE and 33.3 percent of the women had HND or B.Sc while 20 percent received MSc, MA or Ph.D degrees. The remaining 13.4 percent of the respondents claimed to receive some form of other qualifications.

This information shows that well matured individuals are involved in the business of marketing financial resources. Furthermore, table 1 reveals that about 53.3 percent of the women received income between $\$ 101,000$ to $\$ 150,000$ per month, 26.7 percent received income between $\$ 151,000$ above. 13.3 percent received income between $\$ 51,000$ to $\$ 100,000$ while very few of them about 6.6 percent received income below $\$ 50,000$ per month. This figure however excludes the variable pay system adopted by almost all the banks. 
Ibok Nkanikpo Ibok, Etuk Samuel George

Women in Marketing: Their Characteristics, Motivations, Challenges and Policy Implications

Table 1. Socio-economic and demographic characteristics of women in bank marketing

\begin{tabular}{|l|l|l|}
\hline Characteristics & Frequency & Percentage \\
\hline Age (Years) & & \\
\hline Under 30 & 12 & 20.0 \\
\hline $31-34$ & 20 & 33.3 \\
\hline $35-39$ & 12 & 20.0 \\
\hline $40-44$ & 12 & 20.0 \\
\hline $45-$ above & 04 & 6.7 \\
\hline Total & $\mathbf{6 0}$ & $\mathbf{1 0 0}$ \\
\hline Marital Status & & \\
\hline Married & 08 & 13.3 \\
\hline Single & 48 & 80.0 \\
\hline Widow/Separated & 04 & 6.7 \\
\hline Total & $\mathbf{6 0}$ & $\mathbf{1 0 0}$ \\
\hline Educational Level & & \\
\hline FSLC/SC/GCE & 04 & 6.7 \\
\hline OND/NCE & 16 & 26.6 \\
\hline HND/B.SC & 20 & 33.3 \\
\hline M.SC, MA, PhD & 12 & 20.0 \\
\hline Others & 08 & 13.4 \\
\hline Total & $\mathbf{6 0}$ & $\mathbf{1 0 0}$ \\
\hline Income Level & & \\
\hline Below 50,000 & 04 & 6.7 \\
\hline N 51,000 - N 100,000 & 08 & 13.3 \\
\hline 101,000 - N 150,000 & 32 & 53.3 \\
\hline 151,000 - above & 16 & 26.7 \\
\hline Total & $\mathbf{6 0}$ & $\mathbf{1 0 0}$ \\
\hline & & \\
\hline
\end{tabular}

\section{Motivating Forces in the Profession}

On the factors motivating women in this profession varied answers were received from a cross section of women and their responses are presented in Table 2.

Table 2. Motivating factors in the profession

\begin{tabular}{|l|l|l|}
\hline Reasons & Frequency & Percentage \\
\hline Opportunity for self-fulfillment & 15 & 25 \\
\hline Opportunity for career advancement & 10 & 17 \\
\hline Independence/flexible working hours & 15 & 25 \\
\hline Variable income opportunity & 12 & 20 \\
\hline Ability to carry out challenging task & 08 & 13 \\
\hline Total & $\mathbf{6 0}$ & $\mathbf{1 0 0}$ \\
\hline
\end{tabular}

Table 2 reveals that 25 percent of the women are driven by the opportunity for self-fulfillment. Another 25 percent chooses this profession for reasons of being independent and having flexible working hours. 20 percent of the respondents are motivated because of variable income opportunity given by the banks as a percentage of their contribution to target deposit drive, while 17 percent went for career advancement. The remaining 13 percent stated that it gives them opportunity to carryout challenging task.

Challenges faced by women in the course of carrying out their legitimate profession, responses are presented in table 3. 
Table 3. Challenges faced by women in marketing

\begin{tabular}{|l|l|l|}
\hline Challenges & Frequency & Percentage \\
\hline Sexual harassment & 20 & 33.3 \\
\hline Intimidation from clients/management & 12 & 20.0 \\
\hline Insecurity & 10 & 16.7 \\
\hline Sexual discrimination & 08 & 13.3 \\
\hline Unrealistic sales target & 10 & 16.7 \\
\hline Total & $\mathbf{6 0}$ & $\mathbf{1 0 0}$ \\
\hline
\end{tabular}

Respondents were asked to indicate from a range of challenges, those that they faced most in the course of carrying out their marketing duties for the bank. As indicated in table 3 reveals that a good number of them (33.3\%) have sexual harassment as their greatest challenge. 20 percent indicated intimidation from client and management as their major problem. 16.7 percent went for insecurity and unrealistic sales target. Only 13.3 percent went for sexual discrimination or outright bias against women. The socio-economic characteristics of women in marketing, their motivations and their challenges are very consistent with prior research findings (see for example, Cooper, 1981; Belcourt et al, 1991; Timnons, 1986; Neider, 1987 and Goffee and Scasse, 1985).

\section{Conclusion}

Considering various analyses from tables 1 to 3 , the study revealed that there are imperative requirements, techniques and processes to be used in maximizing women potential in marketing profession. Particularly banking industry lays emphasis on deposit drive and this has come to stay in Nigeria. It has immensely alleviated the problem of unemployment and promotes gender equity and women empowerment. Indeed, bank marketing cannot be complete without recognizing the contributions of these women to the profit potential of the banks. All that need to be done is to formally accept and recognize their contribution and think of a realistic measures through policy framework that could enhance their safety and maximize their potentials. Therefore, in the light of the above findings, the following measures are recommended:

(i) Institutional framework designed to protect women in work places should be strengthened and seen not only to be existing but also enforceable to protect women from all forms of biases;

(ii) Improving the socio-economic status of women is a sort of empowerment, therefore, organizational management and government should set up several empowerment programs such as funding and development programs for women in marketing. This will encourage more women participation in the profession;

(iii) As a result of the prevailing challenges, women marketers face in the banking industry coupled with alarming rate of female abuses. It becomes imperative that women protection in marketing should be a matter of national policy in government and non-governmental organizations and adequate attention should be given;

(iv) The totality of women contributions to the development of national economy through marketing are all related to effective utilization and management of women. Managers must understand women role in steering their organizations towards success;

(v) Finally, in view of the potential gains associated with the introduction of marketing in the Nigerian banking industry, there should be a deliberate policy to promote sustainable competition among women in the profession by providing further training and scholarship for women studying marketing in tertiary institutions. This becomes necessary considering the fact that the global economy is agitating for more women participation in many professional activities.

\section{Implications and future Research}

This study is exploratory in nature and we acknowledge its limitations. First, the use of data from a single industry is subject to bias. Secondly, because the data was collected in a specific geographic area, Akwa Ibom State, generalizability is limited. Thirdly, due to limitation regarding our data collection procedure in the coverage of judgmental and convenient sampling methods, we thus acknowledge two related inherent methodological shortcomings 
in this study. Finally, as this study was exploratory in nature, future research should consider larger sample size using other service and manufacturing institutions across all spectrum of the global society to enhance a more generalizable results.

\section{References}

- Adelemo, U. B. (2009) The Woman Entrepreneur: A Career Development Perspective. Academy of Management Science Vol. 8 (2): 86-102.

- Adetiba, M. O. (2009) Women in Engineering Profession: Characteristics, and Challenges Journal of Applied Technological Science. Vol. 8(2):186.

- Adewusi, C. M. (2012) Can the glass ceiling be broken: The Challenges before Women Entrepreneurs. Journal of Psychology and Management. Vol. 4 (8): 138- 152.

- Akpan, I. S. (2009) The Growing Call for Women in Enterprise. A paper presented at a Dinner for Business Gurus in Akwa Ibom State.

- Anyanwu, C. A. (2012). Women and Professional Challenges: The need for enabling Laws. Journal of Business Management. Vol. 6 (4) p. 134.

- Bebbington, B. A. (2001) The Woman Entrepreneur: A Sociological Perspective. Journal of Sociology, Vol. 8(2): 136-152.

- $\quad$ Belcourt, M., Burket, R. J., Lee - Gosseline, H. (1991). The Glass Box: Women Business Owner in Canada. Background paper published by the Canadian Advisory Council on the status of women.

- Comper, A. (1991) Women and Banking: From Rhetoric to Reality: In Managing Change through Global Networking, (ed) I. Heslop, Canadian Consortium of Management Schools.

- Cullerette, P. and Aubry, P. (1990) Socio-economic Evolution of Women Business Owners in Quebec, Journal of Business Ethics, 9, April, p. 417 - 422.

- Fuilamiyo, O. K (2011). Socio-economic dynamics of Women in Management and Organizations, Academy of Business. Vol. 35 (3): 393-402.

- Goffee, R. and Scase, R. (1985) Women in charge: The Experiences of Women Entrepreneurs, London: Allen and Irwin. p. 162.

- Hisrich, R. and Brush, C. (1994) The Women Entrepreneur: Management Skill and Business Problems, Journal of Small Business Management, 22(1), 30-37.

- Ibok, N. I. (2009) Gender Problems and the Upward Mobility of Women Accountants in Akwa Ibom State, Nigeria. Tropical Focus: The International Journal Series on Issues, 9(1) p. 129-135.

- Jacob, H. C. (2013) Critical Success factors of women managers. Journal of Small Business Management and Economics. Vol.8. No. 4, p. 116.

- $\quad$ Kent, C. (1988) Business Education for Women Entrepreneurs. Journal of Business Education, 28-33.

- Kishore, M. (1992) Developmental Needs of Trainers of Women Managers: The Indian Context, Study Report on Women in Management, International Management Institute.

- Lavoice, D. (1992) Women in Business: A Collective Profile, A resource guide to selected research on women owned businesses in Canada (1975-1991). Federal Business Development Bank.

- Lee - Gossedin, H. and Grise, J. (1990) Are Women Owner - Managers Challenging our Definition of Entrepreneurship? An in-depth Survey. Journal of Business Ethics, 9, p. 423-435.

- Lieuanam, J. P. (1992) Women and Governance: The real issues. Journal of Development and Enterprise. Vol. 10(14) p. 236-248.

- Mishra, J. M. (1986). Women Managers in India and US: An Analysis of Attitudes, Myths and Skills (Part 1) Indian Management, 25 (3) p. 25 - 30.

- Mojisola, R. S. (2010) An Exploratory Investigation of Women in Management. Journal of Development Issues Vol. 12 (4): 134-168.

- Morrison, M. J. (2010) Development Programme for Women in Management, Journal of Business and Psychology, 8 (3) p. 124.

- Neider, I. (1987) A preliminary investigation of Female Entrepreneurs in Florida. Journal of Small Business Management 25(3) p. 22-29. 
- Okoruen, M. E. (2012) Evolution of Indigenous Business in South-Western Nigeria. Journal of Cultural Review Vol. 6 (8): 134.

- Olayide, A. K. (1996) Some Methodological Problems associated with researching women in business, Journal of Value Creation and Business Studies Vol. 2(4): 78-98.

- Owen, J. T. (2012) An In depth Study of Women in Bank Marketing: Some Crucial Issues and Implications. Management Review, 2(4): 202-216.

- Patel; V. G. (1987) Women Entrepreneurship Development: In Developing New Entrepreneurs. A Publication of the Entrepreneurship Development Institute of India, Ahmedabad.

- Stevenson, J. A. (1986) Against All Odds: The Entrepreneurship of Women, Journal of Small Business Management; October p. 30-44.

- Susan, A, J. (2010) An overview of research on sex, gender and Entrepreneurship. Journal of Business and Marketing Vol. 16(7), p. 214.

- Timmons, J. A. (1986) Characteristics and Role Demands of Entrepreneurship. American Journal of Small Business, 3 (1) 5-17.

- Utomi, F. B. (2011), Women Entrepreneurship in Nigeria. Institute of Management Development, Uyo, Akwa Ibom State.

- Vaz, I. T. (1987) Women in Banking Sector. Indian Management, 27(4) p. 14-16. 